QUALITY MANAGEMENT STANDARD FOR CIVIL WORKS 


\title{
QUALITY MANAGEMENT STANDARD FOR CIVIL WORKS
}

\author{
MOTOR COLUMBUS Consulting Engineers Inc. \\ $\mathrm{CH}-5400$ Baden, Switzerland \\ SPIE BATIGNOLLES \\ 33, Quai de Dion-Bouton \\ 92814 Puteaux, France \\ SOCOTEC \\ Tour Maine-Montparnasse \\ 33, Avenue du Maine \\ 75755 Paris, France
}

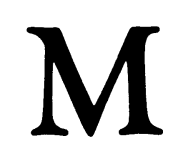

MACMILLAN PRESS

LONDON 
(C)MOTOR COLUMBUS Consulting Engineers Inc., SPIE BATIGNOLLES and SOCOTEC 1984

Softcover reprint of the hardcover 1st edition 1984

All rights reserved. This standard or part thereof may not be reproduced, stored in a retrieval system, or transmitted, in any form or by any means, electronic, mechanical, photocopying, recording or otherwise without the prior written permission of the publishers.

First published 1984 by

THE MACMILLAN PRESS LTD

London and Basingstoke

Companies and representatives

throughout the world

Filmset in 10/11pt Compugraphic Times by

CK Typesetters Ltd., Sutton, Surrey 


\section{Contents}

Introduction $\quad$ vi

QUALITY MANAGEMENT DIRECTIVE 1

QUALITY MANAGEMENT REQUIREMENTS D1 17

(for Design)

QUALITY MANAGEMENT REQUIREMENTS D2 33

(for Design)

QUALITY MANAGEMENT REQUIREMENTS D3 47

(for Design)

QUALITY MANAGEMENT REQUIREMENTS M1 51

(for Manufacturing)

QUALITY MANAGEMENT REQUIREMENTS M2A 71

(for Manufacturing)

QUALITY MANAGEMENT REQUIREMENTS M2B

89

(for Manufacturing)

QUALITY MANAGEMENT REQUIREMENTS M3

95

(for Manufacturing)

QUALITY MANAGEMENT REQUIREMENTS C1

99

(for Construction)

QUALITY MANAGEMENT REQUIREMENTS C2

121

(for Construction)

QUALITY MANAGEMENT REQUIREMENTS C3

(for Construction) 


\section{Introduction}

'QUALITY MUST BE PRODUCED. IT CAN NEVER BE ACHIEVED BY VERIFICATION AND CHECKING ONLY'.

The evolution and growing complexity of techniques and technologies, together with the internationalization of contracts, have led to the use of technicians, materials and equipment from different origins. This and the increasing size of projects, have highlighted the necessity for a specific quality management system that is compatible with the needs of all the parties involved: owners, architects, engineers, contractors, suppliers and independent inspection agencies.

In view of this objective

- MOTOR COLUMBUS Consulting Engineers Inc.

- SPIE BATIGNOLLES

- SOCOTEC

have combined their efforts to develop a Quality Management Standard that can be applied to all kinds of civil works.

To facilitate implementation, the requirements have been established specifically for the following types of activity:

- Design

- Manufacturing

- Construction

This standard has also been structured in such a way as to provide compatibility with the following quality assurance standards and codes of practice:

- IAEA Code of Practice 50-C-QA

- Canadian Standard CSA Z299

- American Standard ANSI N45.2

- British Standard BS 5750

The authors are indebted to the Canadian Standards Association for permission to use CSA Z299 as a springboard for the ideas contained in this Standard. 